\title{
The effect of light intensities on morpho- physiological and biochemical of black pepper (Piper nigrum L.)
}

\author{
Issukindarsyah ${ }^{1 *}$, Endang Sulistyaningsih ${ }^{2}$, Didik Indradewa $^{2}$, and Eka T. Susila Putra $^{2}$ \\ ${ }^{1}$ Bangka Belitung Assessment Institute for Agricultural Technology, Indonesian Agency for \\ Agricultural Research and Development, Ministry of Agriculture, Jakarta, Indonesia \\ ${ }^{2}$ Faculty of Agriculture, Universitas Gadjah Mada, 55281, Yogyakarta
}

\begin{abstract}
The difference in the levels of light intensity was responded with changes in morphophysiological and biochemical characters of plants, especially in leaves of black pepper. The aim of this study was to determine the effect of several levels of light intensity on the morphophysiological and biochemical characters of leaves of black pepper. The research was conducted in July - November 2017 in Kemuja, Mendobarat, Bangka Belitung. This study used split-plot design with three replications. The main plots were the levels of light intensity, namely $100 \%, 75 \%$, and $50 \%$. Subplots were varieties of black pepper, namely Petaling 1, Petaling 2, and Nyelungkup. The results showed that there was no interaction between varieties and light intensities. The morphophysiological and biochemical responses of the leaves of the three varieties tested were the same at all levels of light intensity. Light intensity up to $50 \%$ has no effect on leaf morphological characters, but leaves become thinner at lower light intensities. Chlorophyll, nitrate reductase activity and leaf sucrose concentration were same at all light intensities up to $50 \%$. Plants exposed to higher light intensity have a higher number of stomata. The results concluded that the light intensity of up to $50 \%$ did not cause changes in leaf morphology and biochemistry and only affected leaf stomata density.
\end{abstract}

\section{Introduction}

The important role of light for plants is as a source of energy needed in the photosynthesis process. Leaves are the first plant organs to provide information on changes in the light environment. The response of plants to decreased light is in two ways, which are shade tolerance and avoidance of shade. Shade tolerant plants carry out biochemical, physiological, anatomical and morphological adaptations to improve light interception and suppression. The adaptation is in the form of increasing leaf area ratio, specific leaf area and chlorophyll content [1]. Shade tolerant plants tend to have thinner leaves [2], increase the ratio of leaf area and specific leaf area [3]. The blue spectrum increases the thickness of

\footnotetext{
* Corresponding author: kanggaisyah@gmail.com
} 
the epidermis and palisade of mesophyll cells and the red spectrum decreases the thickness of the abaxial surface and spongy tissues [4].

The adaptation of plants to light conditions varies between species and even for each plant development [5]. Accordingly, the information on the morpho-physiological and biochemical characters of black pepper leaves can characterize varieties that are adaptive to low light intensity conditions. Black pepper requires shade but excessive shade can reduce plant growth and production. Black pepper that uses living support is susceptible to exposure to low light intensity. It happens if the canopy pruning of living support is not routine. According to Wahid [6], pruning of living support carried out three times a year has a light intensity of $65-70 \%$. The light intensity was the best for black pepper growth [7]. The use of varieties that are tolerant of low light intensity is part of an effort to increase the growth and yield of black pepper using living support. Until now, information related to the response of leaf organs in several varieties of black pepper to various levels of light intensity is not available. The objective of this study was to determine the effect of light intensity on the morphophysiological and biochemical characters of leaves of several varieties of black pepper.

\section{Research method}

\subsection{Time and place}

The research was conducted in July-November 2017 in Kemuja village, Mendobarat subdistrict, Bangka district, Bangka Belitung Islands province with an altitude of about $35.5 \mathrm{~m}$ above sea level.

\subsection{Research design}

The study used a split plot design with three replications. The main plot was the level of light intensity namely 100\% irradiation (as control), 75\% irradiation, and 50\% irradiation, and the subplots were three varieties of black pepper, which were Petaling 1, Petaling 2, Nyelungkup. All varieties used were varieties that have been adaptive to the pedoclimate conditions of Bangka Belitung.

The research used polybag seedlings. Black pepper plants were planted under paranet shade with light intensity levels according to each treatment. Shading treatment was given during the five months study. The light intensity in each treatment was observed using a lux meter. Observations were conducted in the morning, afternoon and evening every two days. The spacing used was $80 \times 80 \mathrm{~cm}$. The planting hole was made with a size of $40 \times 40 \times 40$ $\mathrm{cm}$. In the planting hole, $5 \mathrm{~kg}$ of chicken manure and $0.5 \mathrm{~kg}$ of dolomite lime were given about two weeks before planting. Plant maintenance included fertilizing, controlling pests and diseases, installing dead climbing poles and tying climbing vines. Watering the plants was not conducted so that the availability of plant water was only affected by rainfall. The dosage of fertilizer was $25 \mathrm{~g}$ per plant per fertilization for five times [7]. The fertilizers used were nitrogen, phosphorus and potassium (NPK)(15:15:15) and Potassium Chloride $(\mathrm{KCl})$. A week after planting, the plants were given a dead climbing pole with a height of $1.5 \mathrm{~m}$ at a distance of $15 \mathrm{~cm}$ from the base of the stem. Orthotrophic branches were tied to the climbing posts according to the level. 


\subsection{Observation parameters}

The parameters observed included individual leaf area, typical leaf area and typical leaf weight, photosynthetic pigment, stomatal opening width, leaf nitrate reductase activity (NRA) and leaf sucrose content. Sampling was carried out when the plants were five months after planting. Stomata molds were taken during the day on perfectly developed leaves by applying clear nail polish (nail polish) containing the active ingredient nitrate cellulose following standard procedure [8]. After being applied for a few minutes then covered with clear tape and removed. The stomata print in the nail polish was transferred to a slide and observed under a microscope at 10 times the stomatal density and 40x magnification to calculate the length and width of the opening. The microscope was equipped with an optilab viewer v2.1. to calculate the density of the stomata and measure the width of the stomatal opening. Each treatment unit was taken one observation sample each. Chlorophyll a, chlorophyll $\mathrm{b}$ to chlorophyll $\mathrm{a} / \mathrm{b}$ ratio, total chlorophyll and carotenoids ( $\mathrm{mg}, \mathrm{g}^{-1}$ fresh leaves).

Samples came from $1 \mathrm{~g}$ of fully developed leaves of the pepper plant. Chlorophyll was extracted from fresh leaves and then given $20 \mathrm{ml}$ of $80 \%$ acetone which was stirred then filtered using Whatman 41 filter paper, then read with Spectronic 21D at a wavelength of 645 and $663 \mathrm{~nm}$ following the standard procedure by Arnon [9]. Carotenoid levels were read at wavelengths of 480 and $645 \mathrm{~nm}$ and were calculated following the standard procedure [10]. The measurement of nitrate reductase activity followed the standard method [11]. A total of $0.2 \mathrm{mg}$ of leaves sliced with a width of $1 \mathrm{~mm}$. The leaves were put into a film tube containing $5 \mathrm{ml}$ of phosphate buffer solution $\mathrm{pH} 7.0$, then incubated for 24 hours.

The buffer was discarded and replaced with a new buffer of $5 \mathrm{ml}$. A total of $0.1 \mathrm{ml} \mathrm{M}$ $\mathrm{NaNO} 3$ was added as substrate. A dye reagent solution consisting of $0.2 \mathrm{ml} 1 \% \mathrm{SA}$ in $3 \mathrm{~N}$ $\mathrm{HCl}$ and $0.2 \mathrm{ml}$ of $0.02 \% \mathrm{NED}$ was prepared in a test tube. After the incubation time is reached, which is 2 hours, $0.1 \mathrm{ml}$ of the filtrate taken from the film tube is added into the dye reagent and waited for a minimum of 15 minutes or after the pink color appears and then $2.5 \mathrm{ml}$ of distilled water is added. After homogeneous, the solution was transferred to a cuvette, then the absorbance of the solution was measured using a spectrophotometer at 46 wavelengths of $540 \mathrm{~nm}$. ANR was calculated with the formula:

$$
\begin{gathered}
\mathrm{ANR}=(\text { absorbance sampling } / \text { absorbance standard }) \times(1000 / \text { fresh weight }) \\
\times(1 / \text { incubation time }) \times(0.050)
\end{gathered}
$$

Sucrose analysis used the luff schroll method. The analysis was carried out in two stages. Stage 1 before inversion, $2 \mathrm{~g}$ of leaves was crushed using a mortar and then homogenized with $50 \mathrm{ml}$ of distilled water in a measuring flask. A sample of $5 \mathrm{ml}$ was taken and added with $25 \mathrm{ml}$ of luff Schroll solution and 2 boiling stones, connected to a good cooler, and boiled for 10 minutes. After cooling, add $15 \mathrm{ml}$ of $20 \% \mathrm{KI}$ and carefully add $25 \mathrm{ml}$ of $26.5 \% \mathrm{H}_{2} \mathrm{SO}_{4}$ then titrate with standardized $\mathrm{Na}_{2} \mathrm{~S}_{2} \mathrm{O}_{3} 0.2 \mathrm{~N}$ then add $2-3 \mathrm{ml}$ of starch solution. Stage 2 after the inverse: $10 \mathrm{ml}$ of filtrate is taken and put into $50 \mathrm{ml}$ volumetric flask then added $5 \mathrm{ml}$ of $6.76 \% \mathrm{HCl}$ and heated on a water bath at $60 \mathrm{oC}$ for 10 minutes (shake for 3 minutes and leave for up to 10 minutes). Cool immediately to temperature $+20^{\circ} \mathrm{C}$.

Add a few drops of $1 \%$ pp indicator then neutralize with $20 \% \mathrm{NaOH}$ solution until a red color appears. Add drop by drop $0.5 \mathrm{~N} \mathrm{HCl}$ solution until the red color just disappeared then diluted with distilled water until the mark is right. A total of $50 \mathrm{ml}$ until after the inverse put in the Godog taboo and added $25 \mathrm{ml}$ of luff Schroll solution and 2 boiling stones connected to the back cooler then bring to a boil for 10 minutes. Immediately cooled and added $15 \mathrm{ml}$ of $20 \% \mathrm{KI}$ and Carefully added $25 \mathrm{ml}$ of $26.5 \% \mathrm{H} 2 \mathrm{SO} 4$ then titrated with 
using Na2S2O3 $0.2 \mathrm{~N}$ and added a starch solution of 2-3 ml. Make a blank with no sample treatment. Calculated total sugar after inverse with formulas such as the calculation of the total sugar before the inverse, then the total is calculated sugar (\%) with the formula = difference in sugar content after and before the inverse.

The data obtained were analyzed statistically using analysis of variance (ANOVA) so that the effect of varieties and light intensity levels was known. If there is a significant difference, then proceed with the Tukey honestly significant difference (Tukey HSD) test at a significant difference of $5 \%$ using the SAS program.

\section{Results and discussion}

\subsection{Leaf morphology}

Changes in light intensity received by the leaves were detected by photoreceptors, and then transmitted throughout the plant tissue system. Changes in leaf morphology and biochemistry were as in response to and adaptation to changes in the light environment. The results obtained were as informed in Tables 1 and 2. Individual leaf area, typical leaf weight and typical leaf area were not influenced by the interaction of the varieties with light intensity. Individual leaf area, typical leaf weight and typical leaf area were also not significantly different between varieties and between levels of light intensity. This information supports the reports of Wahid [7] that an intensity of $50 \%$ does not have a negative effect on the growth and development of black pepper plants. Thus, it can be stated that black pepper plants exposed to $50 \%$ light intensity do not experience low light intensity stress.

Table 1. Average individual leaf area, typical leaf area, and typical leaf weight of three black pepper plant varieties and three levels of light intensity

\begin{tabular}{|c|c|c|c|}
\hline Treatments & $\begin{array}{c}\text { Average individual } \\
\text { leaf area }\left(\mathrm{cm}^{2}\right)\end{array}$ & $\begin{array}{c}\text { typical leaf } \\
\text { area }\left(\mathrm{cm}^{2} \mathrm{~g}^{-1}\right)\end{array}$ & $\begin{array}{c}\text { typical leaf } \\
\text { weight }\left(\mathrm{g} \mathrm{cm}^{-2}\right)\end{array}$ \\
\hline \multicolumn{4}{|l|}{ Varieties } \\
\hline Nyelungkup & $17.28 \mathrm{a}$ & $112.71 \mathrm{a}$ & $0.009 \mathrm{a}$ \\
\hline Petaling 1 & $19.11 \mathrm{a}$ & $134.47 \mathrm{a}$ & $0.008 \mathrm{a}$ \\
\hline Petaling 2 & $20.46 \mathrm{a}$ & $131.39 \mathrm{a}$ & $0.009 \mathrm{a}$ \\
\hline \multicolumn{4}{|l|}{ Light intensity (\%) } \\
\hline 100 & $16.31 p$ & $105.25 p$ & $0.012 p$ \\
\hline 75 & $20.37 p$ & $127.47 p$ & $0.008 \mathrm{p}$ \\
\hline 50 & $20.17 p$ & $145.84 p$ & $0.007 \mathrm{p}$ \\
\hline Interaction & $(-)$ & $(-)$ & $(-)$ \\
\hline $\begin{array}{l}\text { Coefficient of } \\
\text { variation }(\mathrm{CV})\end{array}$ & $15.24 \%$ & $14.27 \%$ & $20.91 \%$ \\
\hline
\end{tabular}

Notes: The numbers followed by the same letter in the same column are not significantly different at the $5 \%$ significant level. $(-)=$ no interaction

The leaf thickness of the three varieties tested at each light intensity is as in Table 2. Leaf thickness affects the thickness of the palisade tissue and the spongy tissue. Up to $50 \%$ light intensity, leaf thickness, palisade tissue thickness and sponge tissue thickness for each variety were relatively equal. This information shows that the level of sensitivity to changes in leaf anatomy and morphology, especially those related to leaf thickness, is less sensitive to changes in light intensity. As stated in the previous paragraph, the light intensity of $50 \%$ was still in a sufficient range for the growth of the pepper plant so that the adaptation to the light intensity of $50 \%$ was relatively the same as the light intensity of $75 \%$. Plants that were 
sensitive to changes in light intensity, such as blueberries, showed significant anatomical and morphological changes in light intensity levels [12].

Table 2. Leaf thickness, length of palisade tissue and tissue length of sponges of three varieties of black pepper at three levels of light intensity

\begin{tabular}{|c|c|c|c|c|}
\hline Varieties & $\begin{array}{c}\text { Light } \\
\text { intensity } \mathbf{( \% )}\end{array}$ & $\begin{array}{c}\text { Leafthickness } \\
(\boldsymbol{\mu m})\end{array}$ & $\begin{array}{c}\text { Length of palisade } \\
\text { tissue }(\boldsymbol{\mu m})\end{array}$ & $\begin{array}{c}\text { Tissue length of } \\
\text { sponges }(\boldsymbol{\mu m})\end{array}$ \\
\hline \multirow{4}{*}{ Nyelungkup } & 100 & $28.84 \pm 0.583$ & $4.73 \pm 0.396$ & $5.68 \pm 0.275$ \\
\cline { 2 - 5 } & 75 & $28.02 \pm 0.521$ & $4.21 \pm 0.222$ & $4.39 \pm 0.210$ \\
\hline \multirow{4}{*}{ Petaling 1 } & 50 & $27.65 \pm 1.256$ & $4.03 \pm 0.341$ & $4.21 \pm 0.601$ \\
\cline { 2 - 5 } & 100 & $31.62 \pm 0.814$ & $5.34 \pm 0.202$ & $5.56 \pm 0.289$ \\
\hline \multirow{3}{*}{ Petaling 2 } & 75 & $29.98 \pm 0.219$ & $4.70 \pm 0.341$ & $5.56 \pm 0.402$ \\
\cline { 2 - 5 } & 50 & $29.14 \pm 0.742$ & $4.91 \pm 0.220$ & $4.72 \pm 0.187$ \\
\cline { 2 - 5 } & 700 & $29.81 \pm 0.602$ & $4.52 \pm 0.222$ & $4.59 \pm 0.190$ \\
\hline
\end{tabular}

Leaf size expressed as individual leaf area and total leaf area per plant are important factors affecting sunlight capture. Leaves are an important plant organ to meet light needs, especially as a source of energy in the photosynthesis process. Petaling 2 varieties tended to have increased leaf morphological values with a decrease in light intensity by up to $50 \%$, although at each light intensity received; the leaf morphological size was lower than the Nyelungkup and Petaling 1 varieties. In Nyelungkup and Petaling 1, the size of the leaf morphology generally increases when the light intensity decreased from $100 \%$ to $75 \%$. However, when the light intensity was lowered back from $75 \%$ to $50 \%$, the two varieties had smaller leaf morphological sizes.

\subsection{Stomata}

The important role of stomata is as a place for $\mathrm{CO}_{2}$ gas to enter, which is the substrate for photosynthesis, and to exit $\mathrm{O}_{2}$, which is part of photosynthesis products and water vapor. Stomata development is influenced by signals originating from the plant's genetics and environment. The results showed that the number and size of stomatal openings was not affected by the interaction of the varieties with the light intensity level. The number of stomata was influenced by the variety and light intensity, but the width and opening of the stomata were not affected. The number of stomata of the three tested varieties was significantly different, as well as the number of stomata at the three light intensity levels tested was significantly different. The Nyelungkup variety had the highest number of stomata and was followed by Petaling 1 and Petaling 2 while the width and length of the stomata openings were relatively equal (Table 3 ). 
Table 3. Average density, length, and width of the stomatal opening of the three varieties of black pepper and three levels of light intensity

\begin{tabular}{|c|c|c|c|}
\hline Treatments & $\begin{array}{c}\text { Average density of } \\
\text { the stomatal opening } \\
\left(\mathbf{m m}^{-2}\right)\end{array}$ & $\begin{array}{c}\text { Length of the } \\
\text { stomatal } \\
\text { opening }(\boldsymbol{\mu m})\end{array}$ & $\begin{array}{c}\text { Width of the } \\
\text { stomatal opening } \\
(\boldsymbol{\mu m})\end{array}$ \\
\hline Varieties & & & \\
\hline Nyelungkup & $118.93 \mathrm{a}$ & $8.66 \mathrm{a}$ & $2.18 \mathrm{a}$ \\
\hline Petaling 1 & $100.59 \mathrm{~b}$ & $8.32 \mathrm{a}$ & $2.31 \mathrm{a}$ \\
\hline Petaling 2 & $82.94 \mathrm{c}$ & $8.02 \mathrm{a}$ & $1.96 \mathrm{a}$ \\
\hline Light intensity (\%) & & & \\
\hline 100 & $117.85 \mathrm{p}$ & $8.55 \mathrm{p}$ & $2.19 \mathrm{p}$ \\
\hline 75 & $97.19 \mathrm{pq}$ & $8.34 \mathrm{p}$ & $2.18 \mathrm{p}$ \\
\hline 50 & $87.42 \mathrm{q}$ & $8.10 \mathrm{p}$ & $2.09 \mathrm{p}$ \\
\hline Interaction & $(-)$ & $(-)$ & $(-)$ \\
\hline CV & $10.75 \%$ & $12.03 \%$ & $18.74 \%$ \\
\hline
\end{tabular}

Notes: The numbers followed by the same letter in the same column are not significantly different at the $5 \%$ significant level. ( - ) = no interaction

Light intensity up to $50 \%$ affects the number of stomata but does not affect the width and length of the stomata opening. The number of stomata of the lower leaves of the plant that was given a low light intensity of $50 \%$ was the lowest but did not show a significant difference with a slightly heavy light intensity of $75 \%$. The number of stomata at light intensity of $75 \%$ also showed no significant difference with high light intensity of $100 \%$ (Table 3). Until the light intensity of $50 \%$, the width and length of the stomata openings were not significantly different (Table 3 ), but the tendency of the width and length of the stomata openings was shorter at the lower light intensity. This result was in line with the higher number of Lepidium sativum plant stomata on leaves exposed to high light intensity compared to low light intensity [13]. At high light intensity, the leaf size was smaller with a higher cell density. Therefore, the number of stomata per unit leaf area was higher, and vice versa, at low light intensity, the leaf size was larger, which indicates a lower cell density so that the number of stomata per unit leaf area was much lower. It was stated by Wild and Wolf [14] that leaf expansion decreases stomata density. The size and length of the leaf epidermal cells at high light intensity was smaller. At higher light intensity, leaves have the number of cell columns and the number of stomata per cell column was more than at low light intensity so that the reduction in the number of stomata was not due to a decrease in the number of cells per column but because of the loss of several columns [15].

\subsection{Photosynthetic pigment levels}

Light is a source of energy needed by green plants in the light reaction of photosynthesis. Changes in the light environment affect the levels of photosynthetic pigments. The results showed that photosynthetic pigments included levels of chlorophyll a $\left(\mathrm{g}^{-1}\right.$ leaf), chlorophyll $\mathrm{b}$ (per g leaf), chlorophyll a/b ratio $\left(\mathrm{g}^{-1}\right.$ leaf), total chlorophyll $\left(\mathrm{g}^{-1}\right.$ leaf), and carotenoids $\left(\mathrm{g}^{-1}\right.$ leaf) was not affected by interactions between varieties and light intensity. The photosynthetic pigment levels of the three varieties tested were not the same. The levels of chlorophyll a ( $\mathrm{g}^{-1}$ leaf), chlorophyll $\mathrm{b}\left(\mathrm{g}^{-1}\right.$ leaf) and total chlorophyll $\left(\mathrm{g}^{-1}\right.$ leaf) and carotenoids (per g leaf) of Nyelungkup varieties were the highest and significantly different from Petaling 1 and Petaling 2 varieties. Meanwhile, the levels of chlorophyll ( $\mathrm{g}^{-1}$ leaf) and carotenoid ( $\mathrm{g}^{-1}$ leaf) of Petaling 1 and Petaling 2 varieties were equal and not significantly different. All photosynthetic pigment levels (leaf $\mathrm{g}^{-1}$ ) were not affected by light intensity. Up to five months, the plants were given a slightly low light intensity of $75 \%$ and a low of $50 \%$ continuously did not have a significant effect on chlorophyll and carotenoid levels of 
black pepper plants and were equivalent to that of black pepper plants given a light intensity of $100 \%$ (Table 4).

Table 4. Average levels of chlorophyll a, chlorophyll b, total chlorophyll, and carotenoids three varieties of black pepper and three level of light intensity 5 months after planting.

\begin{tabular}{|c|c|c|c|c|c|}
\hline Treatments & $\begin{array}{c}\text { Chlorophyll a } \\
\left(\mathrm{mg} \mathrm{g}^{-1} \text { fresh }\right. \\
\text { leaf weight) }\end{array}$ & $\begin{array}{c}\text { Chloropbyllb } \\
\left(\mathrm{mg} \mathrm{g}^{-1} \text { leaf }\right. \\
\text { fresh weight })\end{array}$ & $\begin{array}{c}\text { Total } \\
\text { chlorophyll } \\
\left(\mathrm{mg} \mathrm{g}^{-1} \text { leaf }\right. \\
\text { fresh weight })\end{array}$ & $\begin{array}{c}\text { Ratio } \\
\text { chlorophyll } \\
\mathrm{a} / \mathrm{b}\end{array}$ & $\begin{array}{c}\text { Carotenoids } \\
\left(\mathrm{mg} \mathrm{g}^{-1} \text { fresh }\right. \\
\text { leaf weight })\end{array}$ \\
\hline Varieties & & & & & \\
\hline Nyelungkup & $0.510 \mathrm{a}$ & $0.618 \mathrm{a}$ & $1.128 \mathrm{a}$ & $0.826 \mathrm{~b}$ & $0.53 \mathrm{a}$ \\
\hline Petaling 1 & $0.473 \mathrm{ab}$ & $0.554 \mathrm{~b}$ & $1.026 \mathrm{~b}$ & $0.857 \mathrm{a}$ & $0.49 \mathrm{~b}$ \\
\hline Petaling 2 & $0.466 \mathrm{~b}$ & $0.466 \mathrm{~b}$ & $1.010 \mathrm{~b}$ & $0.858 \mathrm{a}$ & $0.49 \mathrm{~b}$ \\
\hline $\begin{array}{c}\text { Light } \\
\text { intensity }(\%)\end{array}$ & & & & & \\
\hline 100 & $0.467 \mathrm{p}$ & $0.548 \mathrm{p}$ & $1.015 \mathrm{p}$ & $0.856 \mathrm{p}$ & $0.49 \mathrm{p}$ \\
\hline 75 & $0.489 \mathrm{p}$ & $0.578 \mathrm{p}$ & $1.066 \mathrm{p}$ & $0.847 \mathrm{p}$ & $0.51 \mathrm{p}$ \\
\hline 50 & $0.493 \mathrm{p}$ & $0.591 \mathrm{p}$ & $1.084 \mathrm{p}$ & $0.837 \mathrm{p}$ & $0.51 \mathrm{p}$ \\
\hline Interaction & $(-)$ & $(-)$ & $(-)$ & $(-)$ & $(-)$ \\
\hline CV & $6.19 \%$ & $8.53 \%$ & $7.45 \%$ & $2.80 \%$ & $8.53 \%$ \\
\hline
\end{tabular}

Notes: The numbers followed by the same letter in the same column are not significantly different at the $5 \%$ significant level. ( - ) = no interaction

\subsection{Nitrate reductase activity (NRA)}

Nitrate reductase activity plays a role in converting $\mathrm{NO}_{3}^{-}$to $\mathrm{NO}_{2}{ }^{-}$. Then, by nitrite reductase, it is converted to $\mathrm{NH}_{4}{ }^{+}$as a series of $\mathrm{N}$ assimilation processes that are absorbed by plants in the form of $\mathrm{NO}_{3}{ }^{-}$into amino acids. The results showed that the NRA value was not influenced by the interaction of varieties with light intensity. The NRA value was the same between varieties and was not significantly different. At 100\% light intensity, the NRA was the same as $75 \%$ and $50 \%$ light intensity (Table 5). Light was a signal that regulates the expression and activity of nitrate reductase[16,17]. Increasing light intensity up to $124 \mathrm{mmol} \cdot \mathrm{m}^{-2} \cdot \mathrm{s}^{-1}$ increases NRA of barley leaves [18]. Nitrate reductase activity was also induced by $\mathrm{NO}_{3}{ }^{-}$uptake. At high light intensity $\mathrm{NO}_{3}^{-}$uptake increases so that NRA increases [19]. This is because the movement of $\mathrm{NO}_{3}^{-}$from the soil to the plant canopy follows the mass flow [20]. There is no difference in the NRA between light intensity levels, presumably related to the form of $\mathrm{N}$ fertilizer given in the form of NPK compound fertilizer, hence, $\mathrm{NO}_{3}{ }^{-}$which is absorbed comes from $\mathrm{NO}_{3}{ }^{-}$available in the soil and the results of NPK nitrification. The absorption rate of $\mathrm{NO}_{3}{ }^{-}$is greater at the light intensity which causes the maximum transparency rate, which is the light intensity of $75 \%$. However, if the concentration of availability is the same in the soil the contribution of the high absorption rate, it can be compensated by the uniform availability of $\mathrm{NO}_{3}{ }^{-}$. As a result, NRA on black pepper plants given light intensity $75 \%$ is the same as that given light intensity $100 \%$ and $50 \%$. 
Table 5. Mean NRA threevarieties of black pepper and three levels of light intensity aged 5 months after planting

\begin{tabular}{|c|c|}
\hline Treatments & NRA $\left(\boldsymbol{\mu} \mathbf{g ~ g}^{\mathbf{- 1}} \mathbf{h}^{\mathbf{- 1}}\right)$ \\
\hline Varieties & \\
\hline Nyelungkup & $3.11 \mathrm{a}$ \\
\hline Petaling 1 & $3.28 \mathrm{a}$ \\
\hline Petaling 2 & $3.66 \mathrm{a}$ \\
\hline Light intensity (\%) & \\
\hline 100 & $4.13 \mathrm{p}$ \\
\hline 75 & $2.94 \mathrm{p}$ \\
\hline 50 & $2.99 \mathrm{p}$ \\
\hline Interaction & $(-)$ \\
\hline CV & $11.5 \%$ \\
\hline
\end{tabular}

Notes: The numbers followed by the same letter in the same column are not significantly different at the $5 \%$ significant level. $(-)=$ no interaction

\subsection{Sucrose}

Sucrose is a non-reducing sugar from photosynthesis which has an important role in plant growth and development. The results showed that the levels of leaf sucrose were not affected by the interaction between varieties and light intensity. Leaf sucrose levels were not significantly different between varieties. Leaf sucrose levels in plants exposed to $50 \%$ light intensity were relatively lower than those exposed to $100 \%$ high light intensity. However, leaf sucrose levels between plants exposed to low light intensity were not significantly different from plants exposed to high light intensity (Table 6). The levels of sucrose formed are in line with the photosynthetic apparatus, which are the levels of chlorophyll and stomata. The sucrose content of the Nyelungkup variety was relatively higher than the Petaling 1 and Petaling 2 varieties. The Nyelungkup variety had higher levels of photosynthetic pigment and the number of stomata, but the width and length of the stomata openings were the same so that the amount of sucrose formed was relatively equal. Likewise, the relative sucrose levels were lower in plants that were given a rather low and low light intensity because they had fewer stomata numbers than plants exposed to high light intensity, while the width of the stomatal openings and the chlorophyll levels were not significantly different so that the sucrose levels formed were the same.

Table 6. Average levels of sucrose of three varieties of black pepper and three levels of light intensity

\begin{tabular}{|c|c|}
\hline Treatments & Sucrose (\% w/w) \\
\hline Varieties & \\
\hline Nyelungkup & $0.414 \mathrm{a}$ \\
\hline Petaling 1 & $0.341 \mathrm{a}$ \\
\hline Petaling 2 & $0.347 \mathrm{a}$ \\
\hline Light intensity (\%) & \\
\hline 100 & $0.428 \mathrm{p}$ \\
\hline 75 & $0.358 \mathrm{p}$ \\
\hline 50 & $0.317 \mathrm{p}$ \\
\hline Interaction & $(-)$ \\
\hline CV & $7.45 \% \mathrm{~T}$ \\
\hline
\end{tabular}

Notes: The numbers followed by the same letter in the same column are not significantly different at the $5 \%$ significant level. $(-)=$ no interaction 


\section{Conclusion}

The morphophysiological and biochemical characters of leave of Nyelungkup, Petaling 1, and Petaling 2 varieties cultivated at 50\%,75\%, and 100\% light intensities were the same. The levels of light intensities only affect stomatal density and maximum at $75-100 \%$ irradiation, while the other morphological and biochemical characters are not affected.

\section{References}

1. F. Valladares, Ü. Niinemets, Annu. Rev. Ecol. Evol. Syst. 39, 1, 237-257, doi: 10.1146/annurev.ecolsys.39.110707.173506 (2008)

2. J. J. Casal, S. Avoidance, Arab. B. 10, e0157, doi: 10.1199/tab.0157 (2012)

3. V. Heraut-Bron, C. Robin, C. Varlet-Grancher, D. Afif, A. Guckert, Can. J. Bot. 77, 10, 1425-1431, doi: 10.1139/b99-099 (2000)

4. A.F. Macedo, M.V. Leal-Costa, E.S. Tavares, C.L.S. Lage, M.A. Esquibel, Environ. Exp. Bot. 70, 1, 43-50, doi: 10.1016/j.envexpbot.2010.05.012 (2011)

5. C.D. Jiang, X. Wang, H.Y. Gao, L. Shi, W.S. Chow, Plant Physiol. 155, 3, 1416-1424, doi:10.1104/pp.111.172213 (2011)

6. P. Wahid, Pengaruh pemupukan dan pemangkasan tajar hidup terhadap produksi tanaman lada, Pemb. Littri. 1, 4 (1987)

7. P. Wahid, Pengaruh naungan dan pemupukan terhadap pertumbuhan dan produksi tanaman lada ((Piper nigrum Linn.) (IPB University, Bogor, Indonesia, 1984)

8. D. Indradewa, Gatra agronomis dan fisiologis pengaruh genangan dalam parit pada tanaman kedelai (Univeritas Gadjah Mada, Yogyakarta, Indonesia, 2001)

9. D.I. Arnon, Plant Physiol. 24, 1, 1-15, doi: 10.1104/pp.24.1.1 (1949)

10. G.A. Hendry, J.P. Grime, Methods in comparative plant ecology: a laboratory manual (Chapman \& Hall, London, 1993)

11. H. Hartika, E.J. del Rosario, J.T. Carlos Jr., J. llmu Pertan. 6, 3, 227-235 (1984)

12. S.J. Kim, D.J. Yu, T.-C. Kim, H.J. Sci. Hortic. 129, 3, 486-492, doi: https://doi.org/10.1016/j.scienta.2011.04.022 (2011)

13. M. Vráblová, M. Hronková, D. Vrábl, J. Kubásek, J. Šantrůček, Environ. Exp. Bot. 156, 316-324, doi: 10.1016/j.envexpbot.2018.09.012 (2018)

14. A. Wild, G. Wolf, Zeitschrift für Pflanzenphysiologie. 97, 4, 325-342, doi: 10.1016/S0044-328X(80)80006-7 (1980)

15. G. Allard, C. J. Nelson, and S. G. Pallardy, Shade effects on growth of tall fescue: I. Leaf anatomy and dry matter partitioning. Crop Sci. 31, 1, 163-167, doi: https://doi.org/10.2135/cropsci1991.0011183X003100010037x (1991)

16. C. Lillo, K. Appenroth, Plant Biol. 3, 5, 455-465, doi: 10.1055/s-2001-17732 (2001)

17. D. Pattanayak, S.R. Chatterjee, Biol. Plant. 41, 1, 75-84, doi: https://doi.org/10.1023/A:1001712500451 (1998)

18. H. Gniazdowska-Skoczek, Acta Physiol. Plant. 20, 2, 155-160, doi: 10.1007/s11738998-0007-3 (1998)

19. J.M. Melzer, A. Kleinhofs, R.L. Mol. Gen. Genet. MGG. 217, 2, 341-346, doi: 10.1007/BF02464902 (1989)

20. S.-X. Li, Z.-H. Wang, B. A. Stewart, Adv. Agron. 118, 205-397, doi:10.1016/B978-012-405942-9.00005-0 (2013) 